\title{
Front Matter: Volume 7040
}

, "Front Matter: Volume 7040," Proc. SPIE 7040, Nanobiosystems:

Processing, Characterization, and Applications, 704001 (2 October 2008); doi: $10.1117 / 12.814681$

SPIE Event: NanoScience + Engineering, 2008, San Diego, California, United SPIE. States 


\title{
PROCEEDINGS OF SPIE
}

\section{Nanobiosystems: Processing, Characterization, and Applications}

\author{
Emily M. Heckman \\ Thokchom Birendra Singh \\ Junichi Yoshida \\ Editors \\ 12-14 August 2008 \\ San Diego, California, USA \\ Sponsored and Published by \\ SPIE
}


The papers included in this volume were part of the technical conference cited on the cover and title page. Papers were selected and subject to review by the editors and conference program committee. Some conference presentations may not be available for publication. The papers published in these proceedings reflect the work and thoughts of the authors and are published herein as submitted. The publisher is not responsible for the validity of the information or for any outcomes resulting from reliance thereon.

Please use the following format to cite material from this book:

Author(s), "Title of Paper," in Nanobiosystems: Processing, Characterization, and Applications, edited by Emily M. Heckman, Thokchom Birendra Singh, Junichi Yoshida, Proceedings of SPIE Vol. 7040 (SPIE, Bellingham, WA, 2008) Article CID Number.

ISSN 0277-786X

ISBN 9780819472601

Published by

SPIE

P.O. Box 10, Bellingham, Washington 98227-0010 USA

Telephone +1 3606763290 (Pacific Time) · Fax +1 3606471445

SPIE.org

Copyright (c) 2008, Society of Photo-Optical Instrumentation Engineers

Copying of material in this book for internal or personal use, or for the internal or personal use of specific clients, beyond the fair use provisions granted by the U.S. Copyright Law is authorized by SPIE subject to payment of copying fees. The Transactional Reporting Service base fee for this volume is $\$ 18.00$ per article (or portion thereof), which should be paid directly to the Copyright Clearance Center (CCC), 222 Rosewood Drive, Danvers, MA 01923. Payment may also be made electronically through CCC Online at copyright.com. Other copying for republication, resale, advertising or promotion, or any form of systematic or multiple reproduction of any material in this book is prohibited except with permission in writing from the publisher. The CCC fee code is 0277-786X/08/\$18.00.

Printed in the United States of America.

Publication of record for individual papers is online in the SPIE Digital Library.

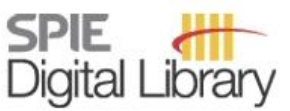

SPIEDigitalLibrary.org

Paper Numbering: Proceedings of SPIE follow an e-First publication model, with papers published first online and then in print and on CD-ROM. Papers are published as they are submitted and meet publication criteria. A unique, consistent, permanent citation identifier (CID) number is assigned to each article at the time of the first publication. Utilization of CIDs allows articles to be fully citable as soon they are published online, and connects the same identifier to all online, print, and electronic versions of the publication. SPIE uses a six-digit CID article numbering system in which:

- The first four digits correspond to the SPIE volume number.

- The last two digits indicate publication order within the volume using a Base 36 numbering system employing both numerals and letters. These two-number sets start with 00, 01, 02, 03, 04, 05, $06,07,08,09,0 \mathrm{~A}, 0 \mathrm{~B} \ldots \mathrm{OZ}$, followed by 10-1Z, 20-2Z, etc.

The CID number appears on each page of the manuscript. The complete citation is used on the first page, and an abbreviated version on subsequent pages. Numbers in the index correspond to the last two digits of the six-digit CID number. 


\section{Contents}

$\checkmark$ Conference Committee

PLENARY SESSION

704002 Revivals of molecular nonlinear optics in physics, chemistry, and life sciences (Plenary Paper [7040-100]

J. Zyss, Lab. de Photonique Quantique et Moléculaire, CNRS, Institut d'Alembert (France)

SESSION 1 BIOLOGICAL SYSTEMS AND APPLICATIONS

704006 Brilliant organic nanodots: novel nano-objects for bionanophotonics (Invited Paper) [7040-04]

O. Mongin, C. Rouxel, A.-C. Robin, CNRS, Univ. de Rennes 1 (France); A. Pla-Quintana, T. Rama Krishna, Lab. de Chimie de Coordination, CNRS (France); G. Recher, F. Tiaho, CNRS, Univ. de Rennes 1 (France); A.-M. Caminade, J.-P. Majoral, Lab. de Chimie de Coordination, CNRS (France); M. Blanchard-Desce, CNRS, Univ. de Rennes 1 (France)

704007 Bioengineered-inorganic nanosystems for nanophotonics and bio-nanotechnology (Invited Paper) [7040-05]

K. Leong, M. T. Zin, H. Ma, F. Huang, M. Sarikaya, A. K.-Y. Jen, Univ. of Washington (United States)

\section{SESSION 2 APPLICATIONS OF DNA-BASED SYSTEMS}

704009 DNA-conductive polymer blends for applications in biopolymer-based field effect transistors (FETs) [7040-07]

F. Ouchen, S. N. Kim, M. Hay, H. Zate, Air Force Research Lab. (United States);

G. Subramanyam, Univ. of Dayton (United States); J. G. Grote, Air Force Research Lab.

(United States); C. M. Bartsch, General Dynamics Information Technology (United States); R. R. Naik, Air Force Research Lab. (United States)

7040 OA Kinetic Monte Carlo study of diffraction grating recording/erasure in DNA-based azo-dye systems (Invited Paper) [7040-08]

A. C. Mitus, G. Pawlik, Wroclaw Univ. of Technology (Poland); F. Kajzar, Lab. POMA CNRS, Univ. d'Angers (France); J. G. Grote, Air Force Research Lab. (United States)

\section{SESSION 3 BIOMATERIALS FOR SEMICONDUCTOR AND SENSING APPLICATIONS}

7040 OC Riboswitch-based sensor in low optical background [7040-10]

S. V. Harbaugh, M. E. Davidson, Air Force Research Lab. (United States); Y. G. Chushak, U.S. Army Medical Research and Material Command (United States); N. Kelley-Loughnane, M. O. Stone, Air Force Research Lab. (United States) 
7040 OE UV lithographic patterning on spin-coated DNA thin-films [7040-12]

D. E. Diggs, J. G. Grote, C. Bartsch, F. Ouchen, Air Force Research Lab. (United States);

A. Sharma, J. M. Taguenang, A. Kassu, R. Sileshi, Alabama A\&M Univ. (United States)

\section{SESSION 4 BIO-POLYMER PHOTONICS}

7040 OG Dye molecular arrangement based on hybridization of DNA (Invited Paper) [7040-14] Y. Ohya, Kansai Univ. (Japan)

$7040 \mathrm{OH} \quad$ Fabrication of waveguide structure of dye-doped DNA-lipid complex films (Invited Paper) [7040-15]

J. Yoshida, T. Tajima, N. Nakai, M. Fukuda, K. Yamaoka, N. Ogata, Chitose Institute of Science and Technology (Japan)

\section{SESSION 5 APPLICATION AND CHARACTERIZATION OF BIO/NANOMATERIALS}

7040 OK Molecular structure and EL application of highly ordered DNA/Ru complex (Invited Paper) [7040-18]

N. Kobayashi, K. Matsumoto, S. Inove, Chiba Univ. (Japan)

\section{SESSION $6 \quad$ INVESTIGATION AND CHARACTERIZATION OF DNA FILMS}

7040 ON Raman microprobe spectroscopic studies of solid DNA-CTMA films [7040-21]

P. P. Yaney, F. Ahmad, Univ. of Dayton (United States); J. G. Grote, Air Force Research Lab. (United States)

7040 OP Stability improvements of DNA photonic devices (Invited Paper) [7040-23]

N. Ogata, K. Yamaoka, Ogata Research Lab., Ltd. (Japan); J. Yoshida, Chitose Institute of Science and Technology (Japan)

7040 OQ Physical properties of natural DNA and metal ion inserted M-DNA (Invited Paper) [7040-24] K. Mizoguchi, Tokyo Metropolitan Univ. (Japan)

\section{SESSION 7 NANOPROCESSING TECHNOLOGIES AND NANOSYSTEMS FOR MEDICAL APPLICATIONS}

7040 OR In vivo blood lactic acid monitoring using microdialysis and surface-enhanced Raman spectroscopy [7040-27]

P.-H. Hsu, National Yang-Ming Univ. (Taiwan) and Tzu Chi College of Technology (Taiwan); T.-H. Tsai, H. K. Chiang, National Yang-Ming Univ. (Taiwan) and Taipei City Hospital (Taiwan)

Author Index 


\title{
Conference Committee
}

\author{
Symposium Chairs
}

David L. Andrews, University of East Anglia Norwich (United Kingdom) James G. Grote, Air Force Research Laboratory (United States)

Kevin J. Liddane, Oerlikon Optics USA, Inc. (United States)

\section{Conference Chairs}

Emily M. Heckman, Air Force Research Laboratory (United States) Thokchom Birendra Singh, Johannes Kepler Universität Linz (Austria) Junichi Yoshida, Chitose Institute of Science and Technology (Japan)

Program Committee

Carrie M. Bartsch, General Dynamics Information Technology (United States)

Liming Dai, University of Dayton (United States)

Ananth Dodabalapur, The University of Texas at Austin (United States) James G. Grote, Air Force Research Laboratory (United States) Kuniharu ljiro, Hokkaido University (Japan)

Jung-II Jin, Korea Academy of Science and Technology (South Korea) Francois Kajzar, Université d'Angers (France)

Norihisa Kobayashi, Chiba University (Japan)

Oksana Krupka, Université d'Angers (France)

Charles Y. C. Lee, Air Force Office of Scientific Research (United States)

Misoon Mah, Asian Office of Aerospace Research and Development (Japan)

Naoya Ogata, Chitose Institute of Science and Technology (Japan)

lleana Rau, Universitatea Politehnica Bucuresti (Romania)

Bruce H. Robinson, University of Washington (United States)

Anna Samoc, The Australian National University (Australia)

Marek J. Samoc, The Australian National University (Australia)

Niyazi S. Sariciftci, Johannes Kepler Universität Linz (Austria)

Andrew J. Steckl, University of Cincinnati (United States)

Morley O. Stone, Air Force Research Laboratory (United States)

Perry P. Yaney, University of Dayton (United States)

Session Chairs

1 Biological Systems and Applications

Junichi Yoshida, Chitose Institute of Science and Technology (Japan) 
2 Applications of DNA-based Systems

Junichi Yoshida, Chitose Institute of Science and Technology (Japan)

3 Biomaterials for Semiconductor and Sensing Applications

Melanie M. Tomczak, Air Force Research Laboratory (United States)

4 Bio-polymer Photonics

Ileana Rau, Universitatea Politehnica Bucuresti (Romania)

5 Application and Characterization of Bio/Nanomaterials

Perry P. Yaney, University of Dayton (United States)

6 Investigation and Characterization of DNA Films

Fahima Ouchen, University of Dayton (United States)

$7 \quad$ Nanoprocessing Technologies and Nanosystems for Medical Applications

Frederic Zenhausern, Arizona State University (United States) 